\title{
Truth and meaning in the maze of irony: A glance at Muriel Spark's fiction
}

\author{
ANNA WALCZUK
}

Received 13.04.2018, received in revised form 15.07.2018, accepted 30.11.2018.

\begin{abstract}
The article addresses the issue of truth and its treatment in the fiction of Muriel Spark (1918-2006), who with her first novel, The Comforters, made her name as a distinctly post-modern novelist. The publication of The Comforters coincided with her conversion to Roman Catholicism, and Spark was explicit about the vital influence which her newly-embraced religion had upon her becoming a writer of fiction. The major point in the following argument is Spark's overt declaration that her writing of novels, which she defines in terms of lies, represents her quest for absolute truth. This apparently paradoxical admission is reflected in Spark's creative output, which combines most unlikely features: postmodernist leanings, commitment to religious belief and a deep-seated conviction on the part of the author about the irrefutable validity of absolute truth. The article focuses mainly on two of Spark's novels: The Only Problem and Symposium, which demonstrate the postmodernist perspective with its insistence on the relativity of truth or its outright negation in the form of the concept of "post-truth". The presented analysis shows how Spark's narratives pursue truth across the multiplicity of continually undermined meanings jointly generated by the text and the reader as its recipient. The discussion emphasises the irony which Muriel Spark proposes as the most effective strategy for getting an inkling of
\end{abstract}


absolute truth, which remains for Spark a solid though evasive value, hidden under the multiplicity of meanings.

\title{
Keywords
}

Muriel Spark, fiction, truth, irony, postmodernism

\section{Prawda i znaczenie w labiryncie ironii - refleksja nad fikcją literacką Muriel Spark}

\begin{abstract}
Abstrakt
Artykuł podejmuje rozważania na temat prawdy w fikcji literackiej Muriel Spark (1918-2006), pisarki angielskiej która już w swojej pierwszej powieści, The Comforters (Pocieszyciele), dała wyraz postmodernistycznemu profilowi własnej twórczości literackiej. Wydanie The Comforters zbiegło się w czasie $z$ jej konwersja na rzymski katolicyzm, a sama pisarka wyraźnie podkreślała wpływ, jaki przyjęcie religii katolickiej miało na jej twórczość powieściopisarską. Główny punkt odniesienia w dyskusji stanowi stwierdzenie Spark, że powieść, która ona sama definiuje w kategoriach fikcyjnego kłamstwa, jest $\mathrm{w}$ istocie poszukiwaniem absolutnej prawdy. To paradoksalne na pierwszy rzut oka wyznanie, znajduje odzwierciedlenia w całej twórczości Spark, która łączy na pozór nieprzystające do siebie elementy, jak postmodernistyczne predylekcje, katolicka religijność, a nade wszystko głębokie przekonanie autorki o niepodważalności prawdy absolutnej. Artykuł skupia się głównie na dwóch powieściach: The Only Problem (Jedyny problem) i Symposium (Uczta), które podejmuja dialog $z$ postmodernistyczna perspektywą relatywizacji prawdy bądź też jej całkowitej negacji w koncepcji “post-prawdy". Przedstawiona analiza ukazuje jak dyskurs narracyjny podąża za wyznacznikiem prawdy mimo, albo przy pomocy, ciąłego podważania cząstkowych znaczeń generowanych łacznie poprzez tekst powieści oraz czytelnika jako odbiorcy przesłania tekstu. Artykuł podkreśla znaczenie ironii, która w powieściach Spark staje się najbardziej efektywna strategia zbliżania się do prawdy absolutnej, a ta w jej twórczości pozostaje wciąż trwała, chociaż nieuchwytna, wartościa skrywana pod wielością znaczeń i interpretacji.
\end{abstract}




\section{Słowa kluczowe}

Muriel Spark, fikcja, prawda, ironia, postmodernizm

The sense that at present we live in what has been termed a post-truth age has pervaded and to a large extent shaped the political and cultural discourse of the twenty-first century. Significantly, the very word "post-truth", which came into general circulation at the beginning of the third millennium, was declared by Oxford Dictionaries as the 2016 word of the year, with a $2,000 \%$ increase in usage when compared to the previous year 2015. No matter how strongly one might oppose the widespread use of the term post-truth, it has to be recognised and intellectually confronted in contemporary critical discourse. "Post-truth" was originally used in reference with politics, and it was in this context that it was introduced in a blog post for the online magazine Grist on 1 April 2010. The blogger wrote: "We live in post-truth politics: a political culture in which politics (public opinion and media narratives) have become almost entirely disconnected from policy (the substance of legislation). This obviously dims any hope of reasoned legislative compromise. But in another way, it can be seen as liberating" (Roberts, Web). Significantly, the term post-truth owes its widespread circulation to electronic media, especially the internet, and however paradoxical it may sound, it has become valid cultural currency in the contemporary world. It is worth noting that "post-truth" has little to do with the temporal or chronological criteria which the prefix "post-" might suggest. It is distinct from lies and falsehood because it builds not so much on distortions of facts as on ignoring them altogether. Thus it advocates the primacy of emotional appeal over factual veracity, and postulates the replacement of processes of verification by compliance with prevailing personal opinions and beliefs. Clearly, "post-truth" concerns the narratives which disconnect a communicative act from any regard for its validation and legitimization in the substance of facts, either experi- 
ential or speculative. Such epistemological dissociation can take place only because truth as such is considered to be of secondary importance. In consequence, in the long run it leads to the undermining of the notion of truth altogether.

When Muriel Spark died in 2006 the term "post-truth" was not yet so popular, but it was already present and easily detectable in many spheres of public life. However, in the field of literature the socio-philosophical phenomenon later known as "post-truth" entered into the domain of novel writing much earlier. Its bold advent coincides with the spread of relativism and the substitution of the democratic rule of a variety of apparently legitimate subjective points of view and highly personalised opinions for the unshakable authority of the absolute. "Post-truth", which primarily started as a political notion, may easily be transposed into a distinctly aesthetic concept in the poetics of postmodernism. It seems that the philosophical framing of postmodernism provides an excellent breeding ground for diverse forms and manifestations of post-truth. The aim of the following discussion is to relate post-modern involvement with post-truth to Muriel Spark's commitment to absolute truth and her specific version of postmodernism. Without doubt Spark can be classified as a post-modern novelist. Martin McQuillan's collection of essays, for example, places her literary output in a clearly postmodernist perspective. Spark's novels show characteristic features of post-modern fiction conceived in terms of the ontological dominant which Brian McHale defined by foregrounding "post-cognitive" aspects (McHale 10), where the prefix "post-" is evidently a significant cultural marker. Postmodern traces and influences can be found in Spark's entire fictional output. They are perhaps least conspicuous in the quasi-autobiographical Mandelbaum Gate (1965), but her first published novel, The Comforters (1957), with its metafictional implications, clearly testifies to the post-modern penchant of Spark's writing. It is worth noting that Patricia Waugh in her well-known study of metafiction 
refers to The Comforters as a very good example of the selfconscious novel.

However, it cannot be denied that Muriel Spark's early pronouncements regarding the status of literary fiction and her explanation of her own reasons for writing novels run against the grain of post-modern questioning of the position and role of truth in the processes of cognition. Unlike the most radical post-modern thinkers and propagators of "post-truth", Muriel Spark does not undermine the validity of truth; nor does she draw a clear demarcation line between truth and fiction, or reality and dream, which is for her a misleading opposition as she demonstrates in her novel bearing this very title, Reality and Dreams (1996). On the contrary, in a clearly nonpostmodernist manner she emphasises the significance of absolute truth as the pivot of her novel writing, and reveals that the quest for truth constitutes both the motive power and the justification of her decision to write novels. Hence, in her interview with Frank Kermode, Spark admits: "I don't claim that my novels are truth [...] I keep in mind specifically that what I am writing is fiction because I am interested in truth - absolute truth - and I don't pretend that what I'm writing is more than an imaginative extension of the truth" (Kermode 1963, 61). Spark treats fiction as lies, but she is far from looking upon lying in the mode of fiction as a departure from, or distortion of truth. That is why her declaration that the lies of fiction are "an imaginative extension of the truth" provides a useful clue to the understanding of her perception of the intricate relation between truth and the novel, which poses a challenge to one of the fundamental assumptions of postmodernism.

The title of this essay evokes truth and meaning as two distinct though interconnected categories. In the subsequent analysis I will try to show how they come to be inscribed into Spark's fiction and how the rhetorical strategy of irony becomes for the novelist an important epistemological path to approach what Spark calls "absolute truth", and for the reader, a means to retrieve the meaning interwoven into the intri- 
cate and multi-layered network of her narratives. At the beginning, however, a brief clarification of the notion of truth is required.

In philosophy there have been many attempts to define truth. However, it remains an evasive concept which nevertheless seeks unconditional acceptance, like axioms in mathematics which are taken for granted. Pontius Pilate's famous question "What is truth?" (see John 18: 37-38) reverberates throughout two millennia of intellectual speculation, and it has become an inseparable part of the cultural discourse of Western civilisation. Muriel Spark's literary debut as a novelist coincided with her conversion to Catholicism, and she made it clear that her decision to become a Catholic was an important step in her life for it helped her to define her own identity as a writer of fiction. In a short autobiographical piece published several years after her conversion Muriel Spark acknowledged the link between her acceptance of the Christian viewpoint and her writing of fiction: "I think there is a connection between my writing and my conversion, but I don't want to be too dogmatic about it. Certainly all my best work has come since then. [...] I find I speak far more with my own voice as a Catholic and I think I could prove it with my stuff" (Spark 1961: 58-63). That is the reason why Spark's "absolute truth" should be viewed from the vantage point of metaphysics rather than as a strictly logical proposition.

Truth is seen by Aristotle in terms of a correspondence to, or with, a fact (Metaphysics 1011b). Thomas Aquinas' wellknown definition, elaborated in Summa Theologiae (Q.16) and De Veritate (Q.1, A.1-3), perceives truth as the equation of a thing and intellect, veritas est adequatio rei et intellectus, and makes the claim that a judgement is true when it conforms to the external reality. In the classic definitions of Aristotle and Aquinas, truth means being in accord with reality. Since the so-called correspondence theory of truth presupposes the correspondence of language and thought to an independent reality, it should be emphasised that for both thinkers, and partic- 
ularly for Aquinas, reality comprises not only the natural world but also the metaphysical realm of the Divine. Spark's "absolute truth" is ontological, and as such it bears a resemblance to the biblical Logos which both orders and explains the world. Such ontological, or absolute, truth comes close to the absolute perfection of the final goal of Hegel's dialectical triplicity, i.e. the continuing movement from thesis, through antithesis, to synthesis, and so on towards increasingly more accurate approximations of absolute truth. The meaning, or rather multiple meanings, discovered in Spark's novels should not be treated as identical with truth, but they should be regarded as cogent pointers to truth. If one adopts the language of metaphor and poetic idiom to the analysis of Spark's novels, meaning can be described as truth's distant relative, or else as its more or less audible harbinger. Such figurative comparison in the critical discourse is not unjustified since Muriel Spark thought of herself primarily as a poet. In Curriculum Vitae (1992) she stresses her leanings towards poetry when she says: "I think of myself as predominantly a poet" (CV: 206). She was seen as such by many of her critics, including Frank Kermode (see Kermode 1971, 267-84) and Malcolm Bradbury (see Bradbury: 137-49).

Muriel Spark's claim that truth is the fundamental issue to be explored across her fiction is presented in imaginative terms in the novel significantly entitled The Only Problem (1984). Its main protagonist, Harvey Gotham, a multimillionaire philosopher totally dedicated to the study of the Book of $J o b$, which he considers to be the "pivotal book of the Bible" (OP: 29), is intrigued by the metaphysical puzzle of Job's undeserved suffering, which he wants to resolve. However, while immersed in his speculative scholarship, Harvey is forced by the circumstances of his life to confront his own personal suffering with the plight of Job, which radically modifies his perspective. The narrative of The Only Problem is governed by the interrogative mode: questions are continually asked, but they are never completely and satisfactorily answered. What is 
more, answers to them cannot even be predicted on the basis of logical assumptions. The gap of unpredictability which becomes an abyss in the process of arriving at truth is epitomised in the character of the main protagonist who is "predictable only up to a point" (OP: 11). In his essays on irony A.E. Dyson underscores unpredictability as an element conducive to ironic discourse, and he claims accordingly: "Neatness and predictability are precisely the qualities that any ironist will mistrust" (Dyson 1965: 121). Apart from underscoring unpredictability, the discourse of the novel oscillates between "what is" and "what is not", and so it persistently evokes "Yes" and "No" as equally plausible answers to the questions that have been implicitly posed. In this way the rhetorical strategy which Muriel Spark employs in her novels, including The Only Problem, makes frequent use of contradictory answers and reversible affirmatives, all of which constitute the proper domain of irony.

The interrogative mode embedded in the narrative structure of The Only Problem is reflected in the imagery framing the narrative. The image which dominates the fictional world of the novel and underpins its setting is the network of roads between Nancy, St Dié and Epinal, among which Spark's characters move as if through convoluted paths of communication in search of answers to unanswerable questions. The topography of the world depicted in the novel bears some resemblance to the setting of T.S. Eliot's "The Love Song of J. Alfred Prufrock", where "Streets [...] follow like a tedious argument / Of insidious intent / To lead you to an overwhelming question ..." (Eliot 2002: 3). The fictional space represented by the grid of crisscrossing motorways becomes a figure of irony adopted by the novelist and offered to the reader as an epistemological path on the way to discovering meaning and, most importantly, to ultimately finding truth. A.E. Dyson compares following the path of irony to being in a maze, and he claims, accordingly, that "irony is as full of unexpected turnings as a maze" (Dyson 1965: 121). The most representative characteristic of irony, 
which is the discrepancy between reality and appearance, underlies all Spark's fictions and represents a conspicuous feature of the narrative discourse and the fictional setting of her novels.

As the plot of The Only Problem gradually unfolds it becomes more and more clear that Harvey will neither solve the metaphysical query concerning God's consent to the infliction of unjust suffering upon the just man, nor find out the truth about his wife Effie. The investigation of Job's predicament is for Harvey like Prufrock's "overwhelming question" - "Everything around him, she knew - all his comings and goings were really peripheral to his preoccupation with the Book of Job" (OP: 39). Coming to grips with "the only problem" of "all his comings and goings", Harvey gets caught in the epistemological trap because his concern with particular meanings impedes him on the way towards absolute truth. He completes writing his exegetic monograph on the Book of Job without finding the answer to his question. However, while pursuing it through contradictory meanings in the maze of irony, Harvey gets an inkling of truth which, paradoxically, is related to the human limitation of knowledge.

Job's problem was partly a lack of knowledge. [...] Everybody talked but nobody told him anything about the reason for his suffering. Not even God when he appeared. Our limitations of knowledge make us puzzle over the cause of suffering, maybe it is the cause of suffering itself. (OP: 111)

In the maze of irony false tracks often have to be taken, while commonly accepted landmarks of conceptual thinking must be sometimes overthrown. Therefore it is not accidental that irony is often perceived in terms of devaluing commonly accepted values. Joseph Dane links this tendency with Socratic irony, claiming that "Socrates devalues what others value" (Dane 1991: 18). The Only Problem shows that the paradigm of questions arduously leading to answers supposedly containing truth may be shattered. Hence the novel generates intimations 
of answers by invalidating questions. From such a perspective Harvey reflects on his seemingly inconclusive experience: "If the answers are valid then it is the questions that are all cockeyed" (OP: 180).

Multiple and equivocal meanings appear as impediments or distracters on the way to truth. Although widespread irony may be viewed as a form of denial and negativity, yet in Spark's fiction it certainly does not deny "absolute truth". In this context it may be appropriate to evoke D. J. Enright's discussion of Socratic dialogues and his claim that even though "uncertainty is intrinsic, of the essence of irony" (Enright 1986: 6), it does not produce the devastating effects of negativity, for it is redeemed by the distinct (although it appears as blurred and distant) objective of truth. Muriel Spark's postmodernist fiction definitely supports this view and testifies to its validity. Anne K. Mellor, likewise, notes the same positive effect of irony when she points to Kierkegaard's argument in favour of Socrates whose "ironic questioning functioned positively" (Mellor 1980: 180).

In Spark's fiction the reader is invited to a symposium of truth-seekers, and that literary symposium comprises all of her twenty-two published novels. One of them is actually entitled Symposium (1990), as it makes an overt allusion to Plato's philosophical text. The analogy is evident not only in the title and the motto of the novel, but also in the setting, which foregrounds a convivial meeting of members of the financial, intellectual and artistic elite who come to the banquet - not, however, in Athens but in Islington, London. The leading motif of the dialogues in Plato's work and Spark's novel is also similar. However, in the post-modern counterpart of Symposium the theme of love from Socratic debate is transformed into the "philosophy of Les Autres", a phrase many times evoked in the novel and mostly associated with Margaret, newly-married to William Damien. Like "modern irony" which, in the words of Charles Glicksberg, "mediates between comedy and tragedy without ever reconciling them" (Glicksberg 1969: 33), Spark's 
narrative oscillates between comedy and tragedy, and so it encompasses the frivolous and trivial, which are placed in the vicinity of the solemn and grave. The posh dinner party comes to an abrupt ending with the arrival of the police informing of the death by strangling of Hilda Damien, William's mother and a would-be guest at the banquet. Before the final disruption of the meeting there are some minor disturbances which destabilise the elegant social decorum by introducing a sense of confusion in the occurrences and thus intensifying chaos, both of which obscure the clarity of vision, and consequently blur truth.

Margaret is the most intriguing character in the novel, and in Symposium, as elsewhere, Muriel Spark is, in the words of one of her critics, "parsimonious in the provision of interpretative hand-outs" (Kermode 1970: 427). Margaret's maiden name, Murchie, is irresistibly suggestive of "murky", meaning dark and unpleasant, but also shameful, which accords with the reputation she has for "the evil eye" (S: 143), attracting trouble and misfortune even without her direct personal agency. Her reputation for working mischief and the surrounding aura of suspicion are not at all unfounded because many deaths and tragic accidents take place in Margaret's proximity: "Margaret's capacity for being near the scene of tragedy was truly inexplicable in any reasonable terms" (S: 142). She is linked by mysterious ties, "an old alliance" (S: 143), with her eccentric Uncle Magnus who suffers from a mental disorder, which, however, makes him more perceptive than most mentally sound people. Uncle Magnus gives the most accurate, and at the same time most ambiguous, appraisal of Margaret, calling her "capable of anything" (S: 80):

What Dan was consulting his brother about, there in the woods walking along the edge of the dark pond, was Margaret. 'Do you think her capable of murdering Mama?'

'I think her capable of anything,' roared Magnus. 'An extremely capable girl, very full of ability, power'. (S: 80) 
Margaret balances on the borderline between nature and the supernatural, and she represents a bundle of contradictions. One of the characters at the dinner party speaks of Margaret as "a female Jekyll and Hyde" (S: 187). Yet if the comparison with Dr. Jekyll and Mr. Hyde is evoked, it has to be emphasised that in the case of Margaret they are not two sides of one personality but a perfect blend, as she is simultaneously a paragon of virtue and a paradigm of vice. In his reflections on irony, Tieck stresses that opposites are reconciled in the ironic awareness that sees unity in duality, which leads to the reconciliation of contradictions without, however, resolving or dissolving them (see Wheeler 1984). In respect of her deviousness Margaret Damien, née Murchie, is a character constructed according to the ironic formula which induces dubiety and brings together affirmation and denial.

The narrative discourse in the novel, like the underlying Socratic debate, is informed by the dialectic between the continual "Yes" and "No" of irony. The progress towards the final goal of truth is made with the help of a rhetorical strategy which Spark called "the nevertheless principle" (Whittaker 1982: 143): each affirmative is modified by "but", "except", etc. This can be seen, for example, in Hilda's general reflection on the Murchies': "They are quite all right but there's something wrong" (S: 54). At the banquet, Margaret loudly articulates her philosophy of les autres and secretly contemplates the murder of Hilda. However, while the guests of the convivial gathering are arguing and speculating, fate operates out of their control or consciousness, regardless of what they say or do. Hilda is murdered by random thieves, absolutely independent of Margaret's scheming, and so Margaret's plan to become an active agent of evil is frustrated by the working of blind chance. Hence Uncle Magnus' words, addressed to Margaret when she speaks of her wish "to actively liquidate the woman" (S: 159), turn out to be prophetic: "destiny might do it for you" (S: 160). Margaret's "wild cry" (S: 191) at the news of Hilda's death is 
the expression of a violent protest raised from the level of humanity against the incomprehensible workings of destiny.

'... I'm very sorry to tell you that Mrs Damien has been the victim of a misfortune. My condolences.' [...]

'No, it can't be,' Margaret shrieks. 'Not till Sunday.' [...] From upstairs comes Margaret's wild cry: 'It shouldn't have been till Sunday!' (S: 191)

The two novels, The Only Problem and Symposium, presented here in greater detail and selected because of their overt and unmistakable references to the question of truth, show Spark's use of irony as a route towards absolute truth, which is hidden under the multiplicity of meanings. No matter how relative and evasive meaning may be in the discursive maze of irony, truth for Spark always remains solid, that is absolute and real, not illusory or subjugated to different vantage points of interpretation. In consequence, many of her novels represent what might appear like a most unlikely blend: attraction to post-modern forms and strategies, commitment to the positive and objective value of truth and the conviction of the significance of religious belief for the craft of the novelist. These seemingly incompatible factors are interlocked in Spark's fiction, and as a distinctive triad which underlies her novels they have to be taken into consideration. In Muriel Spark's novels truth is not worded, but rather cultivated in gaps of silence related to the mystery of existence. However, the search for meaning to which Spark's novels invariably invite the reader, may assist on the way to at least partial unlocking of that mystery. Even though the knot of meanings cannot be easily disentangled, as is often the case with Spark's fiction, this does not in the least preclude the quest for truth in the narrative. In Spark's view the novel is the most suitable medium for such quests, and irony is the best method to adopt. In the interview with Sara Frankel, Spark refers to the significance of novel writing in her life and stresses the close link between the form of the novel and the theme which the form expresses: "A prose style is not just a decora- 
tor's piece of icing on the cake - it's a form of expressing a theme that can't be expressed in any other way" (Frankel 1987: 445). Although the maze of irony in Spark's fiction renders the route towards truth tortuous and meandering, it offers a promise that its twisting and intersecting paths of meaning and understanding lead to the heart of the labyrinth, where the most desired object of the search may be, if not completely grasped, at least partly glimpsed.

\section{References}

Aristotle (2004). The Metaphysics. Trans. Hugh Lawson-Tancred. London: Penguin Classics.

Bradbury, Malcolm (1977). "Muriel Spark's fingernails". In: Patricia Meyer Spacks (ed.). Jersey: Prentice Hall, 137-149.

Dane, Joseph (1991). The Critical Mythology of Irony. Athens - London: The University of Georgia Press.

Dyson, A. E. (1965). The Crazy Fabric: Essays in Irony. London: Macmillan.

Eliot, Thomas Stearns (2002). Collected Poems 1909-1962. London: Faber and Faber.

Enright, D. J. (1986). The Alluring Problem: As Essay on Irony. Oxford - New York: Oxford University Press.

Frankel, Sara (1987). "An interview with Muriel Spark". Partisan Review 54/3: 443-457.

Glicksberg, Charles (1969). The Ironic Vision in Modern Literature. The Hague: Martinus Nijhoff.

Kermode, Frank (1963). "The house of fiction". Partisan Review 30/1: 61-82.

Kermode, Frank (1970). "Sheerer Spark". The Listener 84: 425, 427.

Kermode, Frank (1990 [1971]). "Muriel Spark". Modern Essays. Fontana Press, 267-284.

McHale, Brian (1987). Postmodernist Fiction. New York - London: Methuen.

McQuillan, Martin (ed.) (2002). Theorizing Muriel Spark: Gender, Race, Deconstruction. Houndmills, Basingstoke, Hampshire: Palgrave. 
Mellor, Anne K. (1980). English Romantic Irony. Cambridge, Massachusetts: Harvard University Press.

Roberts, David. "Post-truth politics". Grist. 1 April 2010. Available at <http://grist.org/article/2010-03-30-post-truth-politics/>. Accessed 20.12.2018.

Spark, Muriel (1961). "My Conversion". The Twentieth Century 170/ 1011: 58-63.

Spark, Muriel (1985). The Only Problem. London: Triad Grafton Books.

Spark, Muriel (1991). Symposium. London: Penguin Books.

Spark, Muriel (1993). Curriculum Vitae. London: Penguin Books.

Waugh, Patricia (1984). Metafiction: The Theory and Practice of SelfConscious Fiction. London - New York: Routledge.

Wheeler, Kathleen M. (ed.) (1984). German Aesthetic and Literary Criticism: The Romantic Ironists and Goethe. Cambridge: Cambridge University Press.

Whittaker, Ruth (1982). The Faith and Fiction of Muriel Spark. London: Macmillan.

\section{Abbreviations used for quotations from Muriel Spark's novels}

OP - The Only Problem

$\mathrm{S}$ - Symposium

$\mathrm{CV}$ - Curriculum Vitae

Anna Walczuk

ORCID iD: 0000-0001-8950-7470

Institute of English Philology

Jagiellonian University

Al. Mickiewicza 9A

31-120 Kraków

Poland

anna.walczuk@uj.edu.pl 